\title{
Playing on common ground: spaces of sport, education and cor- porate connectivity, contestation and creativity
}

\author{
Geoffery Z. Kohe ${ }^{1}$ Holly Collison ${ }^{2}{ }^{*}$ \\ ${ }^{1}$ University of Kent, Kent, UK; \\ ${ }^{2}$ Loughborough University, Loughborough, UK[AQ2] \\ *CONTACT Holly Collison h.collison@lboro.ac.uk
}

ABSTRACT

\begin{abstract}
In this article, we examine connectivities within the 'messy' organizational commons of sport, education and corporate partnerships. As scholars forewarned regarding other sectors, there are currently a number of key stakeholders within the commons that that have set agendas, occupied ideological and physical terrain, and legitimized a presence and authority (in particular, the ability to construct and speak a universal 'truths' about sport in specific local, regional and global spaces). The intertwining of organizations here is, we contend, an evident function of an increased symbiosis between sport, education and governmental and nongovernmental stakeholders to carve out significant sector spaces, and exert authority and power over the creation, implementation and ownership 'collaborative' and intersectional work. Drawing on the work of spatial theorists, Henri Lefebvre and Yi Fu Tuan, and focusing on examples from FIFA and the IOC, we present a holistic conceptual framework as a means to understand how global stakeholder relations manifest in regional/local settings. Focusing of processes of thought, production and action, we offer and an intersectional critique of the Sport-Corporate-Education nexus. In addition to revealing the nuances of partnership connections, agendas and outcomes, we argue that within the nexus there exist possibilities and potential for sport education spaces to be reconfigured anew.[AQ3][AQ4]
\end{abstract}

KEYWORDS [AQ5]

\section{Introduction}

Global, national and local spaces have become occupied by sport organizations as part of the processes of modernization. Not unlike in other industries, the quest for spatial colonization has been contoured by a range of contextual forces (e.g. globalization, neoliberalism, geo-political shifts, and diversifying political economies) that have necessitated strategic approaches to sport organizations' work. Scholars have long noted that sport is a 'messy' organizational commons involving a raft of players, networks and connections that are difficult to comprehend and understand, let alone articulate (Chelladurai, 2016; Levermore and Beacom, 2009; Giulianotti, 2015). Reflecting contemporary pressures, a part of sport organizations' colonization of space has entailed forging closer relationships with a varied array of stakeholders (e.g. state agencies, policy makers, corporate entities, educational providers, non-governmental sector players, national governing bodies) (Chatziefstathiou, 2012a; Lenskji, 2012[AQ6]; Holt, 2016; Robinson, Gleddie, and Schaefer, 2016). Although sport organizations and stakeholders may enter into these relationships with their own respective agendas (which also may be competing and in conflict with one another), partnerships are predicated upon sharing, or uniting around, a common ground, goal, aim or objective. Irrespective of whether there is unity of purpose and intent, sport organizations and their stakeholders may differ in the priorities, implementation strategies, measurement mechanisms, and impact or outcome orientations. In addition, organizational coalitions are rarely value and/or obligation free. Rather, partners often enter into established networks and contexts laden with cultural and social meanings and expectations that shape the nature of relationship (Levermore and Beacom, 2009; Meier, 2017; Smillie, Helmich, Randel, and German, 2013).

One area the collective sporting commons has become muddied is the corner where sport organizations, educational providers and commercial agendas intersect. For example, the International Olympic Committee (IOC), National Olympic Committees (NOCs), International and European Football Associations, Premier League Football teams, the United Nations (UN) and its affiliated sub-organizations, national sport federations, and companies like Nike, Adidas, Coca-Cola, and McDonalds, share various educational goals. All have demonstrated either through sport for develop- 
ment projects, creation of education resources, or hosting public events a unified commitment to education; predominantly aimed at young people (Aguinis and Glavas, 2012; Fleming, 2012; Giulianotti, 2015; Kombe and Herman, 2017; Salcines, Babiak, and Walters, 2013). Frequently, the relationships between corporate industry, the sport world and the education domain are couched as part of understandable commercial business. As this article explores, sport organizations and corporations often similarly subscribe to some form of ethics that usually manifests as an altruistic and humanitarian commitment toward civic good or social responsibility. With inherent value-laden and positive undertones, sport (also physical activity and/or physical education), has been used to demonstrate sport organization's and corporate partners' shared commitment to a 'greater good'. Such imperatives are not inherently problematic, yet the use of education also concomitantly serves to legitimize, normalize, promote and privilege sport organizations' commercial relationships and the presence of corporate involvement in educational spaces (Giroux, 2016; Kincheloe, 2002). Moreover, the use of education/educational projects has become a largely unquestioned means to meet corporate social responsibility (CSR) ends and enable corporate entities to politicize educational spaces within specific locales.

Scholarship has already focused on various points of overlap between sport, industry and education (Petrie, Penney, and Fellow, 2014; Harvey, Kirk, and O’Donovan, 2014; Robinson, Gleddie, and Schaefer, 2016). This work has examined how distinct global, economic, social and educational forces (e.g. privatization, marketization, stakeholder engagement, and state intervention) have created conditions for increased intersectionality between sport organizations, commercial stakeholders and sport/physical education providers (Robinson, Gleddie, and Schaefer, 2016; Kohe, 2010; Lenskyj, 2012). This work has highlighted ways both sport and education can, and have, become repurposed, and drawn attention to key questions such as: whose interests and values are privileged at the intersections and in the outcomes?; and, what potential consequences for communities sports organizations and corporate stakeholders seek to influence might be? Following these critiques, in this article we adopt an intersectional approach to examining the intricacies of sport, corporate and education relations. Our aim is to illustrate, by way of football and Olympic vignettes, some of the ways a sport-corporate-education nexus has materialized in (and is sustained via) processes of thought, production and action.

Drawing on evidence from two primary sport contexts (the Olympic movement and Football), we examine points of connectivity, contestation and creativity in sport education initiatives and implementation through global, national and local levels. The focus on FIFA and the IOC reflects these organizations' roles as the most prominent, well-resourced, and politically powerful, sport organizational players within the sector. Furthermore, it is through the respective and intertwined relationship of these sports organizations, and their corporate and international political partnerships that the structural complexities, ideological synergies, global reach and educational infiltration can be explored. Our intentions are essentially threefold: first, to illuminate the discursive nature of organizational connections; secondly, to evidence power relations that emerge within connections and frame production processes; and, third, articulate instances of creativity that may challenge current knowledge construction and ownership. We begin by outlining a conceptual framework of space and its application to understanding the sport-corporate-education nexus.

\section{Conceptualizing sport-corporate-education space}

In the social scientific studies of sport, the notion of space has been used in various ways to examine relationships between physical and cultural practices, individuals, groups, communities and wider territories (Jansson and Koch, 2017). Debates notwithstanding, there is a general recognition that space is a relative, fluid, deep and inter-dimensional concept that can be conceived in practical, political and philosophic terms (Jones et al., 2014; Müller, 2015; Studdert and Walkerdine, 2016). Space has been an attractive concept for sport scholars examining the physical dimensions of sport, and political interactions and identity construction therein (Bale and Vertinsky, 2004; van Ingen, 2003). Within the sociology of sport, for example, an emphasis has been placed on the global, local and global characterization of particular spaces (Guilianotti, 2011[AQ7]; Malcolm, 2012). Research has provided substantive critique of sport mega event sites, the related physical, temporal and geographic specificities of space and assumed harmony or disjuncture(s) with the local sites in which they are entrenched (Gaffney, 2008). Further work has interrogated physical aspects of sporting (and physical activity and leisure) environments, and the sociocultural constituents that make those spaces distinctive (Pretty, Peacock, Sellens, and Griffin, 2005). Collectively, these accounts of space have demonstrated the degrees to which sport is interwoven into geographic landscapes, the significance of sport practices to meaning making within particular spatial communities, and, the relevance of space as a construct to 
'work with' in social research. Taking theoretical cues from this work, in this article our starting point is not initially from a point of physical space, but in recognizing space as holistic way of understanding an intersectional common ground. Our interest is in conceptualizing a philosophical space in which sport, education and corporate practices meet. Subsequent to which, we follow by considering how this intellectual and ideological commons maps out onto physical terrain.

Not unlike previous sport scholars examining space (van Ingen, 2003), for this discussion, we are guided by Lefebvre's (1991a, 1991b) conceptual offerings encouraging a critical appreciation for space as a metaphysical construct. Lefebvre's extensive writings have provided a valuable basis upon which a deeper understanding of space and its meanings may be advanced (Lefebvre, 1991a, 1991b, 1996, 2003; Lefebvre and Réguiler, 1986/2004[AQ8]). Attending to criticism of configurations of the term orientated around structural, institutional, economic and geopolitical bases (understandable in materialistic terms), Lefebvre (1991b) repositions space (or l'space) as transitional (effectively, as a site, or set of sites, in which people, goods, ideas, communities are in perpetual motion). For Lefebvre, the uses of space (should) transcend the urban (and by extension the physical). L'space, Lefebvre contended, is an active creation - a site of constitutive meanings and actions that are simultaneously geographic, social, temporal, physical and inter-dimensional, While l'space is consolidating, crystalizing and crumbling continuously, Lefebvre was not necessarily suggesting such a consideration of space belied tangible interpretations; rather he sought to caution of the difficulties, and essentially futile task, in trying to arrest the space and distil its meaning. Rather, what mattered to Lefebvre was illuminating both the cultural underpinnings of space, to address the necessity of appreciating cultural change as central to the processes of spatial transformation and (re)configuration.

We acknowledge that Lefebvre was not necessarily suggesting that holistic understandings of space were divorced from the practicalities of the physical dimensions. Rather the obverse that spatial renderings are affixed to social, political and geographic referent points. Lefebvre's expression of L'space, Sheilds (1999) offers, is helpful in detaching space from fixed realities of the everyday and for articulating and using space in virtual, transcendental and holistic ways. Importantly, by opening the conceptualization of space to include metaphysical appreciations it becomes possible to also move beyond talking about space in terms of production, and move, rather, toward discussing space as 'a tool of thought and of action' (Lefebvre, 1991, in Gleseking et al., 2014, 289). Moreover, that within this process of thought and action there are inherent forces of power, domination, control and agency in which philosophical dimensions may move to real, practical and consequential.

Lefebvre has not been alone in his efforts to assert a deeper appreciation for space in contemporary scholarship. Tuan (1977), for instance, has also added nuance to the understanding of space as transcendental. In terms of understanding a genesis to Lefebvre's work, Tuan offers useful consideration of the philosophical dimensions and abstract nature of space that are centred on ideas of openness and freedom. For Tuan, space is foremost a metaphysical construct deeply connected to thought, emotion, feeling and embodiment. Taken in unison Lefebvre and Tuan encourage an approach to space that begins in the ether, takes shape through cultural practice, social interaction and physical connection, and is manifest both as a, and through, means of production. We take these principles, and notably the idea that space is innately tied to a commonality of thought and action, forward in our examination of educationally orientated sport projects. Following Lefebvre's encouragement to consider the cultural, deep, inter-dimensional and virtual meanings of space, we put forth the idea of a collective commons; that is an, at first, metaphysical space in which, sport, education and corporate thought collide, create possibilities of production, and generate opportunities for creativity and action. We share Sheilds' (1999) appreciation for Lefebvre in that such theorization is useful for highlighting the fluidities of space and the sparks within spatial connections.

For the focus of our discussion, the spatial ground we are articulating is a one formed upon shared humanitarian ideals about community, belonging, citizenship and pedagogy. Specifically, these have been ideas and principles based on working collectively 'for the greater good' or 'public good', 'doing good, 'contributing to civil society', 'enhancing communities', serving ‘children/young people', or 'those most in need'. Coalter's (2013) critique of sport for development warns practitioners and indeed academics that 'we should be suspicious of any convenient convergence of self-serving interests with the greater good' $(2013,4)$. The common belief systems and objectives of those tasked with selling the idea of sport, raising standards or opportunities for education and producing or funding such ideas as a source of social responsibility have increasingly been criticized as evangelist in tone.

Taking on Lefebvre's abstraction of space, the subsequent section provides a conceptually-based articulation of how processes of thought, production and action coalesce in sport spaces. Drawing on International Olympic Com- 
mittee and FIFA initiatives (specifically, digital sources, publicly available policies and programme documentation), our description of this collective commons specifically considers the emergence and complexities of a recognizable sport-corporate-education nexus. Our interest in is the notion of a commonality predicated on a belief that the sectors of sport, education and corporate business do, and can, share collective beliefs, purposes and objectives.

\section{Discussion}

\section{Thought: sport-corporate-education connectivity}

The ever-changing political climate, global development agendas and awareness of the challenges that local populations and developing nations face, as well as the increased pressures on those in positions of influence and power to enact their corporate and social responsibility precipitates the forging of tighter relations within spaces of thought. The symbolic process of sharing common ideals and engaging in collective spaces of thinking and advocacy is the initial phase of constructing the sport-education-corporate nexus. The convening power and visibility of sport is a natural ideological space for the education and corporate sectors to occupy. These sectors share in their common belief that there are humanitarian, social and educational values to defend, protect and serve (e.g. that sport participation and investment is an altruistic cause, human right and means to global and social citizenship). Yet, as Coalter (2010; 2013) warns, ideological thought becomes a seductive site for evangelists (in this case, sport organizations, corporate and/or non-governmental entities) whom connect in the absence of systemic evidence, questioning or reflection. We bear in mind Coalter's critique in the forthcoming section that examines how the IOC and FIFA connectivity is crafted around particular thought space. We draw attention here to how ideological altruism, formal agendas, public expectations and responsibility afford the sport-corporate-education relationships a modicum of protection against criticism and sustains the connectivity the thought space.

\section{Football thought}

The practice and use of football as a tool for education and social impact is arguably one of the most complex yet notable sites of connectivity within the sport-education-corporate nexus. Under the umbrellas of 'development' and 'education', football as a global, national and local pursuit intersects effortlessly with the notion of civic duty and enhancing educational opportunities. The Federation Internationale de Football Association (FIFA) stands as the governing body for the global game with a mandate of both professional competition and governance with social responsibility and education. Whilst football is the dominant source of connectivity and FIFA stands as the dominant global actor, it is often broad spaces of education and development advocacy where football governing bodies, organizations, high profile teams and athletes share common spaces of thought and ideology.

The diverse opportunities football provides to the philanthropic, commercial and development sectors, facilitates rich spaces of connectivity involving multiple actors, groups and organizations. The pursuit of 'doing good', for example, is captured by FIFA with their 'Hope' program. The association claims, 'through its unique power and universality, football can bring people together, transform lives and inspire entire communities. It creates powerful opportunities to break down barriers to social development, education and health awareness' (2018, n.p.). The 'FIFA for Hope' initiative demonstrates the philosophy of civic duty and the intersection of football, education and development. Regarding connectivity, this provides a linear and aligned stream of thought shared by followers of the game and the cause, from multiple stakeholders from connected sectors.

The connection of others to FIFA's social good and education beliefs is regularly witnessed through the coming together of global leaders and organizations during days of acknowledgement, celebration and awareness. In 2013, the United Nations proclaimed the 6th April as the international day of Sport for Development and Peace (SDP) to 'celebrate the contribution of sports and physical activity to education, human development, healthy lifestyles and a peaceful world' (FIFA, 2017). The shared discourse and advocacy enables networks of stakeholders and fellow believers to share in one space of commonality and connectivity. Global awareness initiatives, SDP festivals and advocacy meetings all facilitate collective thought centered upon an ideal or objective. A FIFA presence is part of their contribution to the cause, not only as a powerful sporting institution but by virtue of the commercial and corporate influence they carry alongside them in these spaces of connectivity. These global initiatives, goals and events draw the commercial sector to this ideological space as an opportunity to exercise their CSR obligations and continue their connection to FIFA. 


\section{Olympic thought}

The key area of IOC's sport-corporate-educational connectivity is the generation of pedagogical projects (Lenskji, 2012; Chatziefstathiou, 2011; IOC, 2017; Naul, Binder, Rychtecky, and Culpan, 2017). One example is the Olympic Values Education Project (OVEP). Launched in 2010, the OVEP centralizes the varied educational work carried out across the world under the IOC's auspices. The OVEP works to 'mainstream Olympic values', provide training provision and education outreach. While the IOC have capacity to undertake their mission unaided, they have enhanced their credibility and power as an educational provider by working in concert with the United Nations Educational, Scientific and Cultural Organization (UNESCO) (United Nations, 2015). Although not always in political synergy (Meier, 2017), given the international reach, sport and educational focus, and development priorities, IOC and UNESCO alignment has become entrenched in recent decades as each express their desires to work in unison for and toward a common civic 'good'. For the OVEP, IOC and UNESCO collaboration has been advantageous. UNESCO already have a significant global presence (working in over 9000 schools in over 180 countries) and already undertake educational and sport evangelism as part of their stated development goals (United Nations, 2015).

Ideological connectivity between the IOC and UNESCO has been enabled by strategic decisions to ensure their work aligns with, influences, and leads global industry guidelines and standards within the sport and Physical Education sector. A key move in this regard was the IOC and UNESCO partnership in 2015 with the International Council of Sport Science and Physical Education (ICSSPE) (and the World Health Organization and other UN organizations) to produce 'action-orientated' Quality Physical Education Guidelines (QPE) (United Nations, 2015). The QPE essentially provides the sector a set of universal policy benchmarks and objectives to drive global reform to improve young peoples' health and wellbeing. Policy alignment and synergy with Physical Education has also been made possible by the UNESCO's lead role within the Intergovernmental Committee for Physical Education and Sport (CIGEPS) (UNESCO, 2017), the IOC's involvement with UNESCO and Non-Governmental agencies in sport and education standard setting, and the subsequent related work of NOCs to work with national policy makers and curriculum providers (Chatziefstathiou, 2011, 2012a, 2012b; Culpan and Wigmore, 2010; Kohe, 2010).

The IOC have adopted the mandate of the QPE within their own, 'Getting coach potatoes off the coach' scheme; undertaken as a pilot with five National Olympic Committees (NOCs) (see IOC, 2015). The scheme encourages NOCs to work with national and local Physical Education and Sport Curriculum providers to implement the QPE guidelines. The work is supported by some of the aforementioned corporate entities and non-governmental agencies including the Commonwealth Secretariat, Laureaus (the 'Sport for Good' organization), 'Reach out to Asia/Qatar' foundation, Australian Aid, Marshall Plan with Africa (part of the German Federal Industry), and Swiss Academy for Development. The strategic accord exemplified with projects like 'Getting the couch potatoes of the couch' demonstrate the IOC's efforts to place the organization as a primary agent in a global(ized) sport educational services sector. Shared thought projects are, however, a rarely benign. Rather, generating ideological space is dynamic process in which agency, power and authority are negotiated and contested.

\section{Production: sport-corporate-education contestation}

For stakeholders to effectively connect and have meaningful presence within spaces connections must go beyond ideals and into the realm of interaction and production. Production serves to manoeuvre commonalities, objectives and resources to establish spatial power, leadership and hierarchies among stakeholders. Organizational power is often historically entrenched and closely associated with the pursuit of legitimacy and authority for achieving social good. Within the sport-corporate-education sector dominant producers of knowledge exert ownership over not only what is produced but in what spaces production occurs, the pace of production, and how the rewards (in terms prestige, brand image and reputation) are returned. Interactions between sport, corporate and education entities, however, do not happen naturally; rather relationship building requires strategies as each partner work out roles, responsibilities and hierarchical position. Within this dynamic, questions may emerge with respect to spatial control, ownership over connections, advocacy agendas, and validation of their global roles, as each stakeholder works to affect their own causes beyond the collaborative. Although the IOC and FIFA may have been dominant colonizers, other actors are present across these spaces who may have the same, or at least, comparable agendas within communities and effect production processes. Production and contestation, we respect, are aligned not only in altruism, but through the process of challenging domination, resistance and the re-imagining of priorities, partnerships and solutions. We acknowledge, therefore, that demonstrations of power and contestation are a necessity of production in order to control deci- 
sion making and produce tangible strategies vis-à-vis social, commercial or educational agendas. Accordingly, this next section explores some aspects of production politics. Our interest lays in articulating stakeholder positions and connections that, while orientated around commonality of altruistic thought, are symbolically charged and power-laden.

\section{Football production}

FIFA has the dual responsibility of governing the international game whilst acting upon the organizations moral and social obligations. Corporate branding and sponsorship is part of the FIFA partnership strategy and this is highly visible within their marketing platforms. In 2005, the FIFA report 'Make the World a Better Place: Football for Hope' outlines their goals, strategies and programmes. The strategic component of this report is particularly insightful, suggesting 'Building up a network of partners with member associations, UN agencies, NGOs, national development and cooperation agencies, and other organizations to implement programmes jointly for the good of human development' is a key part of their collaborative methodology (FIFA, 2005, 13). With the philosophies, ideals and social objectives in place, FIFA's network building model is clear, working exclusively with NGOs, Community-Based Organizations (CBOs), charities, FIFA member associations, non-profit organizations and direct implementers.

The separation between FIFA and its corporate partners is seemingly impossible to achieve. VISA, Coca Cola, Adidas, Sony, Emirate, Hyundai, to name are few, are a consistent presence in all FIFA initiatives. According to the FIFA $(2014,4)$ report, "the "Football for Hope" movement has become an attractive platform for public and private sectors, civil society and multilateral development institutions to invest sustainably and develop innovative partnerships for social development'. This demonstrates the complex nature of collaboration and networks involved in the education and social development goals of the world's governing body for football. Brought together by shared ideals, CSR and investment in the game, there is much to negotiate and manage before the point of implementation. With the corporate backing and identity of FIFA unchallenged it is the 'local' and non-profit sector that bids and grapples to work with the federation. Whilst this seems like an ethical approach to development and education that speaks to the critics of global north privilege and dominance, the corporate lines and power dynamics may not be as fixed nor accounted for as the marketing of this initiative suggests.

This directs our attention to the power relations negotiated in the production phase of constructing relationships and agreements between FIFA, corporate contributors, NGOs and/or local groups. Competitive and contested negotiations organically emerge from the point of connectivity, this is practically activated with an application process to FIFA to evidence experience, skill, track record and capacity. The competition extends beyond the practical processes of formalizing partnerships and successfully bidding for funds, especially in the case of football which draws multiple groups, organizations and individuals into the same physical and connected spaces. There is a clear hierarchical nature within the world of football and those that use football. As such we might suggest that FIFA and its corporate power houses are uncontested in their position at the top, but, those who join the force range from international implementing organizations like UNESCO, UNICEF and Streetfootballworld; who also have recognized status and reputation within the sector. At the other end of spectrum are the local organizations and community groups who jostle for recognition.

\section{Olympic production}

The IOC and UNESCO's collaborative work has necessitated (and been fortified by) support from a 'family' of commercial partners; (Salcines, Babiak, and Walters, 2013). Formally, these partners have been those associated with The Olympic Partner (TOP) programme (in this case, corporations including ATOS, Bridgestone, Coca-Cola, Dow, GE, McDonalds, Omega, Panasonic, P\&G, Samsung, and VISA). The IOC have utilized such partnerships to fund its varied initiatives and outreach work, yet pedagogical co-productions have also been advantageous for corporate stakeholders who have their own distinct commercial imperatives to progress vis-à-vis (corporate) social responsibility. With respect to the aforementioned OVEP programme and IOC/UNESCO productions, a key corporate collaboration has been with the entertainment software company International Sports Multimedia Limited (ISML) (http:// www.ismltd.com/). The ISML have developed a significant reputation for digital content provision across the professional sport sector. ISML have been the official entertainment software licensee of the IOC since the 1998 Nagano Winter Olympic Games and have been at the forefront of various Olympic marketing campaigns, digital and interac- 
tive media initiatives, and progression of e-sport gaming. ISML work with and on behalf of many TOP partners in the production of sport related media content (in particular Olympic-related gaming) and collaborate with companies including Panasonic, Youtube and fellow electronic gaming companies such as SEGA, VG and Ubisoft.

Such sport-corporate-education organizational synergies make sense; particularly if stakeholders share a remit for broadening their respective appeals to a diverse/diversifying youth market (Davies and Bansel, 2007; Gulson, 2008). Alliances also help establish substantial financial and practical platforms upon which the IOC can create and disseminate pedagogical messages. Aspects of the OVEP, and affiliated content provided on the IOC's website and digital channel (www.olympic.org), as well as localized Olympic projects, are reliant on the ISML and TOP sponsors to activate content and ensure attractiveness to the youth market. While the advantages of this production relationship may be evident (particularly in ensuring permanency and resonance of the organization's brand and values), benefits also accrue to corporate stakeholders from Olympic alignment (most notably in affording opportunities to occupy local terrains and communities). Take, for example, Coca-Cola's education project; a school-based business design challenge established in conjunction with the London 2012 Olympic Games. Coca-Cola's education work may be already well-established (see http://www.coca-colacompany.com/stories/education); however, as Coburn and McCafferty (2016) note, such initiatives are rather evidence of the prevailing current of Private Public Partnerships that becoming a ubiquitous feature of the business sector. The project effectively morphed students into quasi-brand ambassadors for the company's stakeholder networking event and enabled Coca-Cola to demonstrate its commitment Olympic family ideals of 'global citizenry', 'social investment' and 'moral altruism' (Coburn and McCafferty, 2016; IOC, 2017).

Within neo-liberalized education spaces, critics have warned these relationships of production are concerning (Friere, 1994 [2014], 2007, 2016; Giroux, 2016, 2017; Kincheloe, 2002, 2008a, 2008b). Namely in that they re-orientate the pedagogical function of communities, schools and education to corporate ends; centralize corporate agendas within education frameworks; legitimize commercial endorsement as routine and unproblematic; and enable corporate stakeholders to have increased power, authority and influence over schools and young people's lives and cultural choices (Giroux, 2016). Production enterprises (such as OVEP, 'Coach Potato' initiative or Coca-Cola's 2012 enterprise) may be tangible outcomes of the connectivity between global constituents in the sport sector. However, without specific spaces in which to orientate activities and communities within which to ply these thought projects, these initiatives consist of only ideological value. Here, then, comes the impetus for the IOC efforts to occupy global, regional and local terrain and colonize communities to their cause(s). By interjecting the organization into varied spaces, the IOC consolidates its presence and that of its partners. Such interjection, however, invariably requires a sensitivity and sensibility toward communities and their contexts.

\section{Action: sport-corporate-education creativity}

FIFA and the IOC's spatial authority is not infallible. Resistance, re-appropriation and unsettling of cultural hegemony is possible in some spaces. Here consideration of Lefebvre's notion of 'the third space' is useful. For Lefebvre, the third space was a construct encapsulating how peoples' lived experiences were a culmination of the processes of thought and production (Sheilds, 1999). Characterized by action, the third space was intended to be transcendental and transformational; that is, to create possibilities for community enterprise and, potentially, revolutionary reactions and new forms of meaning making (Sheilds, 1999). Action entails taking produced meanings and resources (in this case, sport education initiatives and corporatized sport programmes) and translating them in ways that have resonance within specific locales. There is the potential within action for spatial transformation and reconfiguration as knowledge and meanings are altered to fit specific, and familiar, discourses and ideals. With regards to FIFA and IOC enterprises, power, dependency and ownership can shift from these global sector providers and their corporate partners to specific communities. Local points of action manifest themselves in numerous ways; from deciding when and how to engage with football and Olympic projects, exhibiting choice with ways sport organization/corporate materials are utilized, and exploring opportunities to create initiatives that shift current hegemonies and better resonate within specific contexts. Action is, however, not straightforward, but rather necessitates critique and negotiation. Moreover, action comprises innate risk, innovation and creativity as communities seek to find solutions to knowledge transformation that 'work' for them and 'best fit' the physical and philosophical spaces they inhabit. This said, Lefebvre suggested the formation of the third space need not be antagonistic, aggravating, disenfranchising or disconnecting individual and communities, rather (as the examples below evidence), that it becomes a site of mutually advantageous collective spirit. 


\section{Football action}

Between 2005 and 2015 the 'Football for Hope' campaign supported 450 programmes, run by 170 NGOs in 78 countries (FIFA, 2018). Joining them in the pursuit of development through football are a host of commercial and corporate organizations, international facilitators and local implementers. In 2006, the UN chronicle reported on FIFAs approach to 'seek cooperation from specialized organizations with precise know-how and good knowledge of the issues', they provide an example of the collaboration between FIFA and the United Nations Children's Fund (UNICEF) an agency that works in conjunction with NGOs, private-sector companies and other bodies worked together to utilize football's immense popularity (UN, 2006, n.p.). Streetfootballworld provides another example. This global organization has acted as an important partner and facilitator for FIFA's 'Football for Hope' initiative, advising FIFA on their annual allocation of 1.5 million dollars of funding, thus sustaining support for their local partners. The global appeal, networks and reach of football and its social and educational agenda is, from the periphery, seamless. The power of football, FIFA and its corporate and international partners allows for the seemingly effortless flow of funds to local groups to enact their imaginations and creativity. This hands-off approach arguably allows a sense of cultural ownership and creates a power shift that sees local leaders and groups enact their knowledge centred on their everyday realities and embodied understanding of local needs and meaningful football interventions.

Despite the relative ease at which FIFA and its collaborators ideologically connect, forge partnerships, and allocate funding, the action phase is less simple to define and evaluate. The notion of 'development' and 'action' requires a contextual approach mindful of top-down bottom-up perspectives. The power shift experienced in the action stage may be considered either a symbolic gesture or political decision. Yet, this experience of agency and power is fragile and may come at a price. Academic enquiry has long criticized evaluation procedures especially in relation to power, politics and dominant voices (see Kay, 2012[AQ10]; Nicholls, Giles, and Sethna, 2011, 250). Potentially, we might position this as a necessary evil aligned to the sport-education-corporate nexus, with an understanding that local ownership of sport for education programmes are hinged and reliant on conforming to the formal requirements of funding and sustaining relationships with the powerful.

Another critical perspective has centred on the re-emerging principles of integrity and dependency questioned within FIFA and development more broadly. Levermore (2010) suggests that many projects are poorly linked to core business objectives and the tarnished reputation of sport is problematic for CSR for development through sport. Such perspectives become particularly significant when analysing FIFA's approach, objectives and moral stance given their long-term reputation for corruption and questionable governance. We might suggest that local engagement and empowerment is part of the symbolic gesture of civic duty whilst simultaneously reimaging an identity and brand through the nexus. Political and power relations aside, the global reach of funds, facilities and programs that have enabled local groups and populations to benefit and engage with educational opportunities and football participation should be recognized.

\section{Olympic action}

The collaborations between organizations like the IOC, UNESCO and partners such as the ISML and Coca-Coca demonstrate how a sport-corporate-education nexus may be created and operationalized to serve specific, largescale, commercial and ideological agendas; and, in the case of sport, aid spatial colonization and domination with the sector. In this sense, the nexus can be understood as a both space of stakeholder connection and production, but also as a mechanism enabling members to create and advocate a particular world view (e.g. the IOC's and UNESCO's version of what humanitarian sport work might effectively 'look' like, and who it might be for, and in what spaces it might be played out). Yet, as organizations work with(in) local communities, processes of negotiation, resistance, and redevelopment may come to fore and, importantly, creative opportunities may emerge that recraft prevailing ideological doctrine to better speak to the needs, desires and distinct contexts of local spaces. One example is Get Set; the digital Olympic education platform initially built for the London 2012 Olympic Games (http://www.getset.co.uk/) and the related Kent 20 in 12 initiative.

Get Set provides opportunities for a wide array of communities (particularly schools and sports clubs) to utilize its educational material and disseminate 'Olympic' values. The site has also been developed further (e.g. for the 2014 Commonwealth Games in Glasgow and subsequent sport-mega events). However, aspects of its content and resources are restricted and require formal registration, copyright exists for some resources and site use, and currently the 
site maintains a strategic pedagogical monopoly over the digital production of (Olympic) sport/humanitarian values resources. Notwithstanding its content, Get Set still necessitates a certain degree of translation to turn sport-corporate-education thought and production into action. Local providers, for example, must choose how best to engage with the resource and alter material to be contextually relevant; essentially 'fit-for-purpose' within specific community spaces.

In contrast, the Kent 20in12 initiative was one instance of spatially-(re)orientated action. The programme entailed the Kent County council in the United Kingdom drawing on aspects of Get Set, and working in dialogue with local schools, sport service providers and a higher education institute, to create 12 specific learning projects to deliver to the region's young people (Kohe and Chatziefstathiou, 2017[AQ11]). Kent 20in12's primary emphasis was encouraging active citizenry and leadership. While many of the values and ideals of the programme reflect those undertaken in IOC and corporate projects (and still, in part, reiterate, Olympic ideology), the distinction is that the cultural ownership of knowledge, and the authority to produce new meanings and experiences, within the local spaces that was not contingent on IOC diktats or corporate glorification and affiliation. Kent 20 in 12 also worked from the ground-up; incorporating local sector voices to craft initiatives that spoke to extremely local communities' (which ranged from well-socioeconomically advantaged to resource-poor and impoverished spaces) characteristics, needs and desires. In the interest of democratizing pedagogy, and unlike Get Set, the programme operated as an open access resource that is maintained with the aid of local and national government funding but is not regularly updated. The spirit of the initiative has, however, been adopted in local and regional sport and education strategies (e.g. Medway Council's Sport Strategy, 2016).

\section{Conclusion}

The intention of this article has been to craft a conceptual framework in which a holistic notion of sport, education and corporate space might be imagined. What the IOC and FIFA vignettes highlight is that there is not, necessarily, a linear system of knowledge production and dissemination. Rather, the sport-corporate-education nexus is a dynamic system that entails considerable action, agency and power struggles as ideas are produced, knowledges are translated into particular spaces, and localized meaning making is undertaken. In such processes/practices, communities should not be considered as passive recipients, but rather constituents of creative potential. While there might be an initial point of ownership or delegation of responsibility within the relationship, over time, as the relationship moves through thought, production and action the space becomes muddied. The examples evidence that stakeholders, invariably, want to occupy spaces together-and, essentially, need each other to fulfil their varied purposes; particularly, toward humanitarian and social responsibility. To return to the question posed at the outset of article, it is evident there is an inherent hierarchy within the sport-corporate education nexus in which sport organizations (primarily the IOC and FIFA) and entities such as the UN and WHO are placed at the apex, these are supported by commercial stakeholders, and then latterly education developers and providers.

There is often a tendency within academic critique to focus on the detrimental aspects of stakeholder connections and consequences, thus positioning sport spaces as problematic. While we acknowledge that this maybe accurate in some cases, the examples we have used demonstrate sport is a place of potential positive action, opportunity and creation. Notwithstanding, the substantive influence of major stakeholders within the industry who endeavour to shape the educational and development consequences of sport on grand scales, by the time initiatives get to the local level (as witnessed with the Football for Hope and Kent 20 in 12 projects) there are opportunities for powershifts as dominant players are removed from the process once it gets to the point of creativity. The localization of power may, in turn, be utilized to shape and reimagine knowledge creation and applied outcomes in ways that may best reflect the specificities of context and lead to sustainability. The critique offered in this article acknowledges commonality; however, the framework we have adopted goes beyond the commonality and considers the points leading to production and the layered agendas and processes behind action. In proposing a sport-corporate-education nexus we, essentially, advocate for the formation of a knowledge and action commons in which organization, industry and pedagogical agendas are synergized toward collective ends. While such a nexus may crystalize institutional hegemonies and power structures, we argue that the constantly evolving spaces provide possibilities for creativity, empowerment, re-colonization and reconfigured ownership.

\section{Disclosure statement}

No potential conflict of interest was reported by the authors.[AQ12] 


\section{References}

Aguinis, H., and A. Glavas . 2012. "What We Know and Don't Know about Corporate Social Responsibility a Review and Research Agenda." Journal of Management 38 (4): 932-968. doi:10.1177/0149206311436079.[AQ13]

Bale, J. and P. Vertinsky, eds. 2004. Sites of Sport: Space, Place, Experience. New York: Routledge.

Chatziefstathiou, D. 2011. "Olympism: A Learning Philosophy for Physical Education and Youth Sport". In Introduction to Sport Pedagogy for Teachers and Coaches: Effective Learners in Physical Education and Youth Sport, edited by Armour, K.M. Harlow: Pearson.

Chatziefstathiou, D. 2012a. "Olympic Education and Beyond: Olympism and Value Legacies from the Olympic and Paralympic Games.” Educational Review 64 (3): 385-400. doi:10.1080/00131911.2012.696094.

Chatziefstathiou, D. 2012b. "Active Citizens and Public Policy: The Example of London 2012 Olympic Games." International Journal of Sport Management, Recreation and Tourism 9: 23-33. doi:10.5199/ijsmart-1791-874X-9b.

Chelladurai, P. 2016. "Corporate Social Responsibility and Discretionary Social Initiatives in Sport: A Position Paper.” Journal of Global Sport Management 1 (1-2): 4-18. doi:10.1080/24704067.2016.1177355.

Coalter, F. 2010. "The Politics of Sport-for-Development: Limited Focus Programmes and Broad Gauge Problems?" International Review for the Sociology of Sport 45 (3): 295-314. [AQ14]doi:10.1177/1012690210366791.

Coalter, F. 2013. Sport for Development: What Game are we Playing. Oxon: Routledge.

Coburn, A., and P. McCafferty . 2016. “The Real Olympic Games: Sponsorship, Schools and the Olympics - The Case of Coca-Cola." Taboo: The Journal of Culture and Education 15 (1): 23-40

Culpan, I., and S. Wigmore . 2010. "The Delivery of Olympism Education within ….ysical Education Context Drawing on Critical Pedagogy.” International Journal of Sport and Health Science 8: 67-76. doi:10.5432/ ijshs.20090028.

Davies, B. D., and P. Bansel . 2007. "Neoliberalism and Education.” International Journal of Qualitative Studies in Education 20 (3): 247-259. doi:10.1080/09518390701281751.

FIFA. 2005. "Make the world a better place." FIFA: Football for Hope. http://www.fifa.com/mm/document/afprograms/worldwideprograms/fifa_ffh_en_1851.pdf

FIFA. 2014. "Report: Football for hope festival, Caju - Rio de Janeiro.” Football for Hope Festival 2014 Report. https://img.fifa.com/image/upload/e2n2xcqryofaprkdskdl.pdf

FIFA. 2017. "FIFA celebrates International Day of Sport for Development and Peace.” FIFA News. http:// www.fifa.com/sustainability/news/y=2017/m=4/news=fifa-celebrates-international-day-of-sport-for-developmentand-peace-2878446.html

FIFA. 2018. "Football for hope: Sustainability." FIFA News. http://www.fifa.com/sustainability/football-forhope.html

FIFA. (nd). "Football for hope: Football's commitment to social development." FIFA. http:// www.centrostudisport.it/PDF/FIFA/215.pdf

Fleming, P. 2012. The End of Corporate Social Responsibility: Crisis and Critique. London: Sage.

Friere, P. 1994. Pedagogy of Hope: Reliving pedagogy of the oppressed. New York: Bloomsbury.

Friere, P. 2007. Daring to Dream: Toward a Pedagogy of the Unfinished. Oxon: Routledge.

Friere, P. 2016. Pedagogy of Indignation. Oxon: Routledge.

Gaffney, C. T. 2008. Temples of the Earthbound God: Stadiums in the Cultural Landscapes of Rio De Janeiro and Buenos Aires. Austin: University of Texas Press.

Giroux, H. A. 2016. Stealing Innocence: Corporate Culture's War on Children. New York: Palgrave. 
Giroux, H. A. 2017. "Democratic Education under Siege in a Neoliberal Society”. In Teaching for Democracy in an Age of Economic Disparity, edited by Wright-Maley and Davis, T., 13-24. London: Routledge.

Giulianotti, R. 2011. "Sport, Transnational Peacemaking, and Global Civil Society: Exploring the Reflective Discourses of "Sport, Development, and Peace” Project Officials." Journal of Sport and Social Issues 35 (1): 50-71.

[AQ15]doi:10.1177/0193723510396666.

Giulianotti, R. 2015. “Corporate Social Responsibility in Sport: Critical Issues and Future Possibilities.” Corporate Governance: The International Journal of Business in Society 15 (2): 243-248. doi:10.1108/CG-10-2014-0120.

Gleseking, J. J., M. Mangold, C. Katz, S. Low, and S. Saegert, eds. 2014. The People, Place, and Space Reader. New York: Routledge.

Gulson, K. N. 2008. "Neoliberal Spatial Technologies': On the Practices of Educational Policy Change.” Critical Studies in Education 48 (2): 179-195. doi:10.1080/17508480701494226.

Harvey, S., D. Kirk , and T. M. O’Donovan . 2014. "Sport Education as a Pedagogical Application for Ethical Development in Physical Education and Youth Sport." Sport, Education and Society 19 (1): 41-62. doi:10.1080/13573322.2011.624594.

Holt, N. L., ed. 2016. Positive Youth Development through Sport. 2nd ed. Oxon: Routledge.

International Olympic Committee (IOC). 2017. "Getting the couch potatoes off the couch: IOC joins forces with UNESCO to improve physical education in schools." Olympic News. https:/www.olympic.org/news/-getting-thecouch-potatoes-off-the-couch-ioc-joins-forces-with-unesco-to-improve-physical-education-in-schools International Olympic Committee (IOC). 2017. Olympic Charter. Lausanne: International Olympic Committee. Jansson, D., and N. Koch . 2017. "Toward a Critical Geography of Sport: Space, Power, and Social Justice”. In Critical Geographies of Sport: Space, Power and Sport in Global Perspective, edited by Koch, N. (ed.), 237-252. London: Routledge.

Jones, M., R. Jones, M. Woods, M. Whitehead, D. Dixon, and M. Hannah . 2014. An Introduction to Political Geography: Space, Place and Politics. Oxon: Routledge.

Kay, T. 2012. "Accounting for Legacy: Monitoring and Evaluation in Sport in Development Relationships." Sport in Society 15 (6): 888-904. doi:10.1080/17430437.2012.708289.

Kincheloe, J. L. 2002. The Sign of the Burger: McDonald's and the Culture of Power. Philadelphia, PA: Temple University Press.

Kincheloe, J. L. 2008a. Knowledge and Critical Pedagogy: An Introduction. New York: Springer.

Kincheloe, J. L. 2008b. Critical Pedagogy. 2nd ed. New York: Peter Lang.

Kohe, G. 2010. 'Disrupting the Birds' Nest: 'Show Case China - Beijing 2008' and Socio-Historical Challenges for Olympic Education.” Sport, Education and Society 15 (4): 479-494. doi:10.1080/13573322.2010.514742.

Kohe, G. Z., and D. Chatziefstathiou . 2017. “Olympic Education in the United Kingdom: Rethinking London 2012, Learning 'Legacies' and their Pedagogical potential”. In Olympic Education: An International Review, edited by Naul, R., Binder, D., Rychtecky, A. and Culpan, I. 3rd ed., 60-72. Oxon: Routledge.

Kombe, C. L. M., and C. Herman . 2017. "Can Educational Innovations Be Sustained after the End of Donor Funding? The Case of a Reading Educational Programme in Zambia." Educational Review 69 (5): 533-553. doi:10.1080/00131911.2016.1265917.

Lenskyj, H. J. 2012. “Olympic Education and Olympism: Still Colonizing Young People’s Minds.” Educational Review 64 (3): 265-274. doi:10.1080/00131911.2012.667389.

Lefebvre, H. 1991a. The Production of Space, translated by Nicholson-Smith, D. Oxford: Blackwell.[AQ9]

Lefebvre, H. 1991b. The Critique of Everyday Life, Vol.1, translated by Moore, J. London: Verso.

Lefebvre, H. 1996. Writings on Cities, edited and translated by Kofman, E., and Lebas, E. Oxford: Blackwell.

Lefebvre, H. 2003. Key Writings, edited by Elden, S., Lebas, E., and Kofman, E. Oxford: Blackwell. 
Lefebvre, H., and C. Réguiler . 1986. Rhythmanalysis: Space, Time and Everyday Life, translated by Elden, S., and Moore, G., 87-100. London: Continuum.

Levermore, R. 2010. "CSR for Development through Sport: Examining Its Potential and Limitations." Third World Quarterly 31 (2): 223-241. doi:10.1080/01436591003711967.

Levermore, R. and A. Beacom, eds. 2009. Sport and International Development. New York: Palgrave.

Malcolm, D. 2012. Globalizing Cricket: Englishness, Empire and I. London: Bloomsbury.

Medway Council. 2016. Medway Sporting Legacy 2017-2020: Play, Compete, Spectate. Chatham, UK: Medway Council.

Meier, C. 2017. "The Early Relationship between UNESCO and the IOC: Considerations-Controversies-Cooperation.” Diagoras: International Academic Journal on Olympic Studies 1:229-248.

Müller, M. 2015. “Assemblages and Actor-Networks: Rethinking Socio-Material Power, Politics and Space.” Geography Compass 9 (1): 27-41. doi:10.1111/gec3.12192.

Naul, R., D. Binder, A. Rychtecky, and I. Culpan, eds. 2017. Olympic Education: An International Review. New York: Routledge.

Nicholls, S., A. R. Giles, and C. Sethna . 2011. "Perpetuating the 'lack of Evidence' Discourse in Sport for Development: Privileged Voices, Unheard Stories and Subjugated Knowledge." International Review for the Sociology of Sport 46 (3): 249-264. doi:10.1177/1012690210378273.

Petrie, K., D. Penney, and S. Fellows . 2014. "Health and Physical Education in Aotearoa New Zealand: An Open Market and Open Doors?" Asia-Pacific Journal of Health, Sport and Physical Education 5 (1): 19-38. doi:10.1080/18377122.2014.867791.

Pretty, J., J. Peacock , M. Sellens , and M. Griffin . 2005. "The Mental and Physical Health Outcomes of Green Exercise.” International Journal of Environmental Health Research 15 (5): 319-337. doi:10.1080/09603120500155963.

Robinson, D. B., D. Gleddie, and L. Schaefer . 2016. "Telling and Selling: A Consideration of the Pedagogical Work Done by Nationally Endorsed Corporate-sponsored Educational Resources." Asia-Pacific Journal of Health, Sport and Physical Education 7 (1): 37-54. doi:10.1080/18377122.2016.1145430.

Salcines, J. L. P., K. Babiak, and G. Walters . 2013. Routledge Handbook of Sport and Corporate Social Responsibility. New York: Routledge.

Sheilds, R. 1999. Lefebvre, Love \& Struggle: Spatial Dialectics. New York: Routledge.

Smillie, I., H. Helmich, J. Randel , and T. German, eds. 2013. Stakeholders: Government-NGO Partnerships for International Development. New York: Routledge.

Streetfootballworld. 2016. "Football for hope: Programme support." Street Football World Project. http://www.streetfootballworld.org/project/football-hope-programme-support

Studdert, D., and V. Walkerdine . 2016. "Space, Geography and Social Power." In Rethinking Community Research, 127-160. Basingstoke, UK: Palgrave Macmillan.

Tuan, Y. F. 1977. Space and Place: The Perspective of Experience. Minnesota: University of Minnesota Press.

UNESCO. 2017. "Learning to live together: Physical education and sports." UNESCO News. http:// www.unesco.org/new/en/social-and-human-sciences/themes/physical-education-and-sport/

United Nations. 2015. Transforming Our World: The 2030 Agenda for Sustainable Development. New York: United Nations.

United Nations. 2006. "FIFA and the United Nations educating the most underprivileged through sport." UN Chronicle. Vol. XLIV, No. 4. https://unchronicle.un.org/article/fifa-and-united-nations-educating-most-underprivilegedthrough-sport

Sport in Society, 0 (2017), (C) 2018 Informa UK Limited, trading as Taylor \& Francis Group $10.1080 / 17430437.2018 .1555219$ 
van Ingen, C. 2003. "Geographies of Gender, Sexuality and Race: Reframing the Focus on Space in Sport Sociology." International Review for the Sociology of Sport 38 (2): 201-216. doi:10.1177/1012690203038002004. 


\section{AUTHOR QUERIES}

Query: AQ1: Please review the table of contributors below and confirm that the first and last names are structured correctly and that the authors are listed in the correct order of contribution. This check is to ensure that your names will appear correctly online and when the article is indexed.

\begin{tabular}{|l|l|l|l|l|}
\hline Sequence & Prefix & Given name(s) & \multicolumn{2}{l|}{ Surname Suffix } \\
\hline 1 & & Geoffery Z. & Kohe & \\
\hline 2 & & Holly & Collison & \\
\hline
\end{tabular}

Response: Resolved

Query: AQ2: Please provide department/division name if any for both affiliations and check whether the affiliations are OK as set.

Response: Resolved

Query: AQ3: As per the journal style, reference citations are not allowed and hence removed from the abstract. Please provide citation for reference "Davies, 2010".

Response: I am not sure what the correction refers to as there is no Davies (2010) mentioned in the abstract. If, elsewhere, there is no corresponding reference then the citation can be removed.

Query: AQ4: The abstract is currently too long. Please edit the abstract down to no more than 150 words.

Response: In this article we examine connectivities within the \&lsquo;messy\&rsquo; organizational commons of sport, education and corporate partnerships. As scholars forewarn, there are currently key stakeholders within the commons that that have set agendas, occupied ideological and physical terrain, and legitimized a presence and authority. The intertwining of organizations here is an evident function of an increased symbiosis between sport, education and governmental and non-governmental stakeholders to carve out significant sector spaces, and exert authority and power over the creation, implementation and ownership \&lsquo; collaborative\&rsquo; and intersectional work. Drawing on spatial theorists, Henri Lefebvre and Yi Fu Tuan, and examples from FIFA and the IOC, we present a conceptual framework of global stakeholder relations. Focusing of processes of thought, production and action, we offer an intersectional critique of the nuances of Sport\&ndash;Corporate\&ndash;Education nexus and consider possibilities and potential for sport education spaces to be reconfigured anew.

Query: AQ5: Please provide 3-5 keywords.

Response: Spatial theory, stakeholders, education, corporatisation, Lefebvre

Query: AQ6: Please note that the reference "Lenskji, 2012" is cited in the text but is not listed in the references list. Please either delete the in-text citation or provide full reference details following journal style.

Response: Please add in the following to the reference list.Lenskyj, H. J. (2012) 'Olympic Education and Olympism: Still colonizing young people's minds', <em>Educational Review, 64</em> (3): 265-274.

Query: AQ7: Please note that the reference "Guilianotti, 2011" is cited in the text but is not listed in the references list. Please either delete the in-text citation or provide full reference details following journal style.

Response: Please add the following to the reference list:Giulianotti, R. (2011) \&lsquo;Sport, transnational peacemaking, and global civil society: Exploring the reflective discourses of \&ldquo;sport, development, and peace\&rdquo; project officials\&rsquo;, J<em>ournal of sport and social issues, 35</em> (1): 50-71.

Query: AQ8: Please check the year in reference citations “Lefebvre and Réguiler, 1986/2004".

Response: The citation is correct. The end reference is as follows:Lefebrve, H. \& R\&eacute;guiler, C. (1986/2004 [Elden, S. \& Moore, G. trans]) <em>Rhythmanalysis: Space, time and everyday life</em>. London: Continuum, 87-100.

Query: AQ9: Please mention if it is "a" or "b" for reference citation "Lefebvre, 1991".

Response: Resolved

Query: AQ10: Please note that the year for "Kay 2010" has been changed to 2012 to match the entry in the references list. Please provide revisions if this is incorrect.

Response: Resolved

Sport in Society, 0 (2017), (C) 2018 Informa UK Limited, trading as Taylor \& Francis Group $10.1080 / 17430437.2018 .1555219$ 
Query: AQ11: Please note that the year for "Kohe and Chatziefstathiou, 2015" has been changed to 2017 to match the entry in the references list. Please provide revisions if this is incorrect.

Response: The correct 2017 (as below) should be added to the reference list. The 2015 citation can be maintained also.Kohe, G.Z. \& Chatziefstathiou, D. (2017) \&lsquo;Olympic Education in the United Kingdom: Rethinking London 2012 learning \&lsquo;legacies\&rsquo; and their pedagogical potential\&rsquo;, in Naul, R., Binder, D., Rychtecky, A. \& Culpan, I. (Eds.) <em>Olympic Education: An International Review.</em> London: Routledge, 60-72.

Query: AQ12: A disclosure statement reporting no conflict of interest has been inserted. Please correct if this is inaccurate.

Response: Resolved

Query: AQ13: Please provide missing DOI number for all journal-type references.

Response: Resolved

Query: AQ14: Please note that the reference "Coalter 2010" is listed in the references list but is not cited in the text. Please either cite the reference or remove it from the references list.

Response: Resolved

Query: AQ15: Please note that the reference "Giulianotti 2011" is listed in the references list but is not cited in the text. Please either cite the reference or remove it from the references list.

Response: Resolved

\section{COMMENTS}

C1 Author: doi: 10.31390/taboo.15.1.05; : 